\title{
Article
}

\section{England is the World and the World is England}

\author{
Asa Simon Mittman \\ Department of Art and Art History, California State University, Chico, CA, USA.
}

\begin{abstract}
Medieval Christians arguably lived in a 'real' world - a tangible place in which they lived, worked, loved, hated, and died - but through a process of worldbuilding continually reconstructed it anew around themselves as the mythical land they called 'Christendom.' This was predicated first on reconceptualizing and then ultimately on removing (or attempting to remove) the non-Christians in their midst. In twelfth- and thirteenth-century England, Jews were the prime focus of such efforts, demonized and monsterized, and then expelled en masse. Still, it seems that every work that seeks to reconstruct England by othering Jews also undercuts its efforts by collapsing differences in time and space, so that England becomes everywhere, and the present moment becomes everywhen. This brief essay will consist of a whirlwind tour through the Hereford Map, tracing various vectors along its buckling surface, to and from that small, marginalized protuberance at the lower-left corner of creation Britain.
\end{abstract}

postmedieval: a journal of medieval cultural studies (2018) 9, 15-29.

https://doi.org/10.1057/s41280-017-0067-x

'I didn't mean to kill her. Really, I didn't. It's just that he was on fire.'

- Dorothy, The Wizard of $\mathrm{Oz}$ (1939)

Medieval Christians arguably lived in a 'real' world - a tangible place in which they lived, worked, loved, hated, and died - but through a process of worldbuilding they continually reconstructed it anew around themselves, transforming it into the mythical land they called 'Christendom.' ${ }^{1}$ This was, of course, one

1 My thanks to Leila K. Norako for inviting me to write this essay and for her insightful editing of it. 
of many imagined worlds they (like all peoples) built and rebuilt constantly. Christendom was predicated first on reconceptualizing and then ultimately on attempting to remove the non-Christians in their midst. In twelfth- and thirteenth-century England, Jews were the prime focus of such efforts, demonized and monsterized in image and text, and then expelled en masse in body. To say that anti-Jewish rhetoric, verbal and visual, laid the groundwork for the expulsion would be to present the process as more deliberate that it was, but this rhetoric was nonetheless the necessary predicate for the expulsion. In order to link disconnected individuals, groups, and events, English illuminators had to collapse differences in time and space; they thereby reconstructed their kingdom so that England became everywhere, and the present moment became everywhen. In so doing, they strove to grant their imaginary world tangible reality. Their acts of imagination thereby had physical, at times violent and devastating consequences. We tend to think of world-building as an enjoyable act of fiction, set in fantasy novels and science fiction film. The world-building that occurs on and through maps of real territories, though, becomes inextricable from those territories themselves, and the people who live within them. While most scholarship on the rhetorical power of maps to enact change in the world focuses on later maps, it is likewise true of the wondrous, grand medieval genre of mappae mundi, or world maps - literally 'cloths of the world,' as the Middle Ages had no word that would properly translate to the present day English 'map.' Catherine Delano-Smith and Roger Kain argue that the mappa mundi is 'undoubtedly the most idiosyncratic, even spectacular, map genre of all times, and was of particular importance in England' (Delano-Smith and Kain, 1999, 37). These maps aim to encompass not merely the geographical scope of the world, but the entire universe around it, as well as all of human and divine history. Mappae mundi are encapsulations not only of knowledge geographical and political but also anthropological, zoological, botanical, hydrological, astronomical, mythological, atmospherical, and eschatological. They are universal diagrams, encyclopedic charts that reflect the 'overwhelmingly bookish or clerkly character' of the Middle Ages (Lewis, 1964, 5). The most 'spectacular' of these mappae to survive is the Hereford Map, a massive work with over one thousand images and inscriptions arrayed across its eighteen and a half square feet of trapezoidal vellum (Figure 1). It was probably made at or near Hereford Cathedral, and likely hung in one of the transepts as part of a pilgrimage route to the relics of Thomas de Cantilupe, sainted anti-Semitic bishop of Hereford (d. 1282) (Terkla, 2004, passim; de Wesselow, 2013, passim; Kupfer, 2016, 15-29; Finucane, 2004, n.p.; and Tout, 1886, 450).

The Hereford Map, like all world maps, is a work of concerted worldbuilding, in turn nested within the larger project of the construction of 'Christendom.' It does not chart a preexistent reality, but rather, establishes a new reality toward which the inhabitants of the old terra cognita aspired. As 


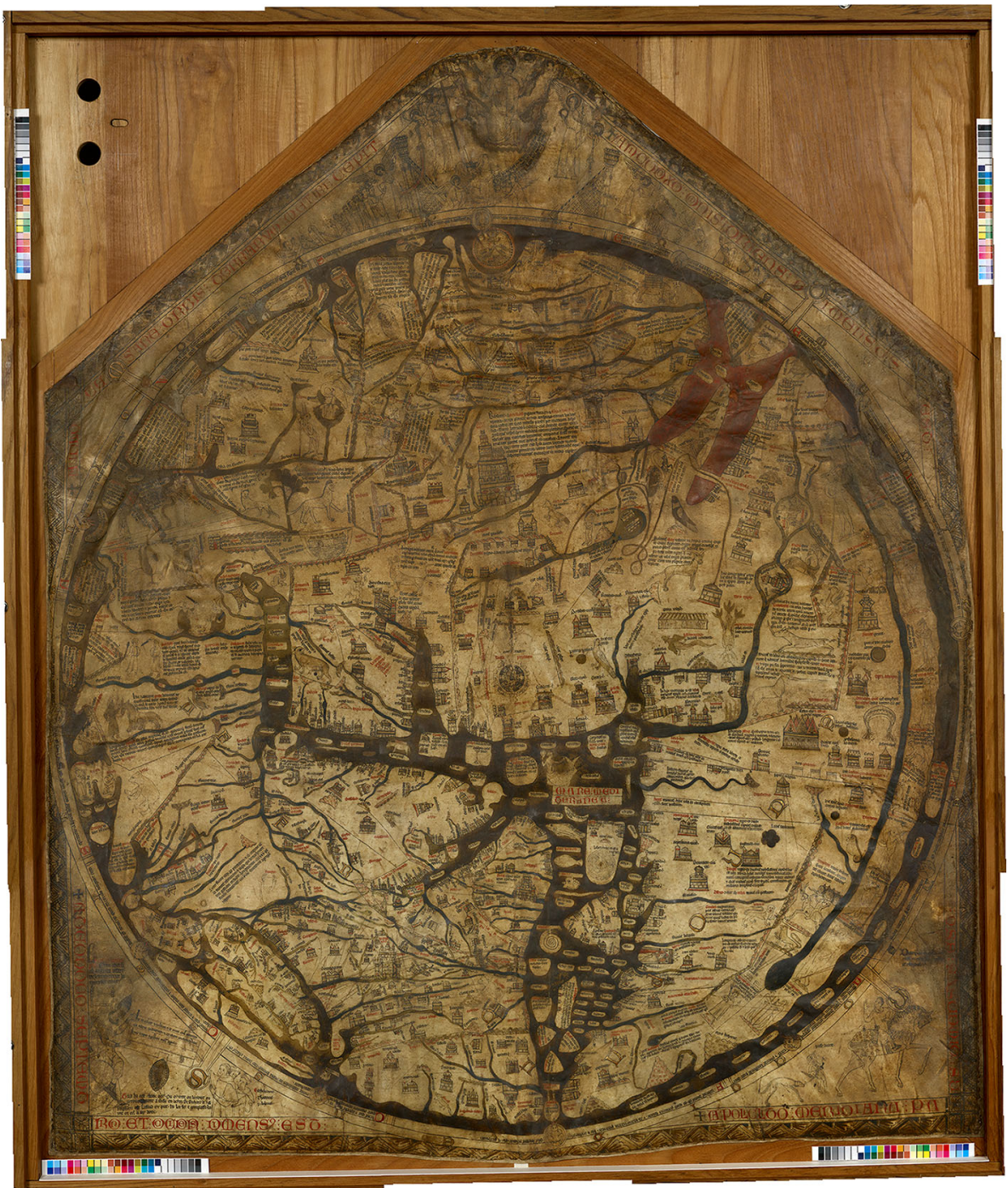

Figure 1: Hereford Map, Hereford Cathedral, ca. 1303, by permission of the Dean and Chapter of Hereford and the Hereford Mappa Mundi Trust.

cartographic theorist Denis Wood argues, '[t]here is nothing natural about a map. It is a cultural artifact, an accumulation of choices made among choices every one of which reveals a value: Not the world [...] as it is' (Wood et al., 2010, 108). It bears mentioning that Wood is primarily discussing modern maps, those seemingly transparent, 'scientific' maps that we often take for granted. His assertion is all the more true - or at least, all the more apparent when applied to medieval mappae mundi. 
All maps, then, map what we might think of as imaginary worlds, since they can never capture the vast complexity of the territories they present, and were they to, pace Borges, their utilities to us would vanish (Borges, 1975, 131). This is true of modern maps, as Denis Wood details at length, but the mythohistorical, religiotemporal nature of medieval maps brings such world-building to the fore (Wood et al., 2010, passim). The ecumene, the inhabitable land on which medieval mappae mundi focus, is no less imaginary than the maps of Middle Earth on the endpapers of a Tolkien novel. We might well have traveled to cities that bear the same names as some of the vignettes on the Hereford Map - London, Paris, Rome, Hereford, and so on - but we have not actually traversed the territory of the map. They are self-contained imaginary worlds that differ from other genres in that they are not 'strictly determined by the narrative line (or lines) they contain.' Rather, imaginary worlds are filled with narratively extraneous details that 'provide background richness and verisimilitude to the imaginary world' (Wolf, 2012, 2). The status of the mapped territory as imaginary, though, does not render it less important than it would be were it somehow, impossibly, a direct transfer, a contact print flawlessly indexing its referent. Instead, its very status as unavowedly imaginary grants the map much of its force. As Mark Wolf writes, 'Imaginary worlds are sometimes very important to their creators and central to their own lives,' and 'invite audience participation in the form of speculation and fantasies' (Wolf, 2012, 5, 13). This describes very well the dynamic interaction of a viewer with the space created within a mappa mundi. We lean over or stand before them and chart our varied paths throughout their enticing, alarming, and impossible territories.

The Hereford Map is a richly complex work, with no single path through it, no 'main theme.' Rather, there are many threads we could follow, many a spoor toward which, following King Alfred the Great, we might 'bend with our mind' ['to ðæm spore mid ure mode onlutan'] (Cassidy and Ringler, 1971, 181). In this short essay, I will roam over the Hereford Map, tracing a few key vectors along its buckling surface. I will focus on the manner in which the mapmaker creates relationships between some of the map's images of Jews and a marginalized protuberance at the lower-left corner of its recreation of Creation: Britain. In so doing, I hope to tie the world-building project of the mapmaker to the larger world-building projects of the medieval English church and crown, and stress how these projects led to dire consequences for some people living in the overlapping and imbricated worlds drawn on the map's surface. As the ruling powers of England were working to recreate their kingdom as a newly (and illusorily) homogenous emulation of the imagined heavenly kingdom they sought, they commissioned maps. They deployed these world-building projects in royal and ecclesiastical spaces, from Henry III's Westminster Palace to Hereford Cathedral, in private, personal prayer books, like the British Library's royal Map Psalter, and in the most public of venues, like the pilgrimage route in Hereford. 
A quick orientation to the Hereford Map is necessary. Facing the east, the map shows the three landmasses known to medieval geographers: Asia, Africa, and Europe. The vertical Mediterranean divides Europe and Africa, with the Nile bending off to the right and dividing Southern Africa, filled with monstrous peoples, from the rest of the ecumene. At the center is Jerusalem, walled and inaccessible. Around the rim of the world, there are many monsters predominately hybrids of humans, animals, and plants (Mittman, 2006, 39-41). And, at the lower left corner, crammed into a bite taken out of the world's circle, are the British Isles.

As David Woodward argues, '[t]he function of the mappae mundi was primarily to provide a visual narrative of Christian history cast in a geographical framework, not to communicate geographical or cosmographical facts' (Woodward, 1985, 519). Alessandro Scafi elaborates on this notion at length, and concludes that 'the idea of progression of history from east to west lies at the heart of the mappa mundi' as a genre (Scafi, 2006, 127). This presentation of chronology is central to the effort on the Hereford Map to present England as a prototype or a harbinger of an imminent 'Christendom.' Much of the map is explicitly embedded in the past. It presents, for example: Adam and Eve in Eden, and then being expelled just outside it; Noah's ark, still occupied by his family; the Wandering of the Israelites; Moses's receipt of the Ten Commandments; the Crucifixion; and so on.

In sharp contrast with the past events on the map, as Debra Strickland has argued, England is eminently contemporary in its presentation (Strickland, 2015, 12-13). That is, much of the map shows the past, but England is shown in a very immediate medieval present. The currency of the image of England is most explicit in the Lincoln vignette. Lincoln had housed a major Jewish community in the thirteenth century, and became a center of anti-Semitic violence (Hillaby, 2013, 47). The image of the city on the Hereford Map prominently features Steep Hill, a formerly Jewish neighborhood, evacuated of its inhabitants in Edward's Edict of Expulsion of 1290; Edward then claimed many of the Steep Hill properties, three of which are carefully rendered on its slope in the vignette (Strickland, 2015, 12-13). This allusion to recently shifted property and territory signals that the Hereford Map's England is current, timely, of its moment. It also emphasizes that this England is one free of the contrived 'Jewish menace.' In this way, England as depicted in Hereford serves as a microcosmic example of the aspirational world-building we see on the map as a whole, as a prototype for the longed-for Christendom, which could be achieved by extending this model across the ecumene. This small detail serves to remind us that while, of course, medieval maps were often based on earlier prototypes, they also are products of their own specific place and time of production, such that each map, as Marcia Kupfer writes of Hereford, is 'an original synthesis of all its iconographic parts' (Kupfer, 2016, 32). Indeed, even if the earlier, pre-expulsion map on which the Hereford Map was presumably 
based (possibly produced by the 'Richard of Holdingham or of Sleaford' named in its dedicatory inscription, Kupfer, 2016, 31-32) also had a vignette of Lincoln showing Steep Hill, the valence of those three houses would be entirely different than they are on the post-expulsion Hereford Map. Perhaps, like Borges's fantasy of a word-for-word rewriting of Cervantes's early seventeenth-century Spanish masterpiece by the twentieth-century French 'Pierre Menard, Author of the Quixote,' the supposed mere copy might be 'more subtle' than the original, such that 'the second is almost infinitely richer' (Borges, 1999, 93-94).

Where are the Jews in the world of the Hereford Map, if not in England? This depends on how literal we are. The most prominent indication of a Jewish presence is in the southeast (upper left) quadrant of the map, just below the bifurcated Red Sea: the path of the Israelites, wandering in the desert for forty years. Just above the peak of this coiling path, between the forks of the Red Sea, is Moses, horned and kneeling on a coffin, receiving the Ten Commandments. Just northeast of Moses, in an architectural frame, is a figure that may be Abraham. In the center of all of these details, between the two arms of the path of the Israelites and the two arms of the Red Sea, is a cluster of four figures kneeling in worship before an idol atop an altar. These figures are labeled 'Jews' ['Iudei'], though they - like the wanderers - are technically still 'Hebrews' or 'Israelites' within the Biblical narrative, since Moses has not yet descended from the mountain with the Law. They are presented in long robes with deep cowls and wide sleeves, beneath which they wear tighter tunics. Their hair is smoothly combed over the crowns of their heads and cropped into a fringe of tight curls around this. This is to say that they are dressed and groomed as is common for English men c. 1300. In particular, their cowled robes recall monastic dress. Their medieval robes and hairstyles compound the anachronism of their inscription, combining to conflate an ancient group with a contemporary medieval group (Lavezzo, 2011, 367-68 and Leshock, 2002, passim). The presentation of the 'Jews' works synchronously with the representation of Steep Hill in Lincoln. Both imbricate time periods in order to shunt the Jewish people back and forth across time and space. They are presented both as ancient people and as present problems, and as unchanging since the time of Moses, indeed, since their idol worshipping days prior to the receipt of Mosaic law. Anachronism, in other words, becomes integral to the world-building of the Hereford map, specifically insofar as it attempts to cordon off the Jewish people as separate from the rest of the world, locked into a malignant past and unchanged in practice into the medieval present. Since the world the mapmaker is striving to call into being is 'Christendom,' there is no place in it for peaceful coexistence with contemporary Jewish groups. In the map's images and texts, Jews seem to fluctuate in name and appearance, but do so in order to convey the map's message: the Jews should be not only over there but also back then.

There are also four references to Gog and Magog on the map, and a quick glance at other maps reveals that these are proxies for Jews (Figure 2). This 


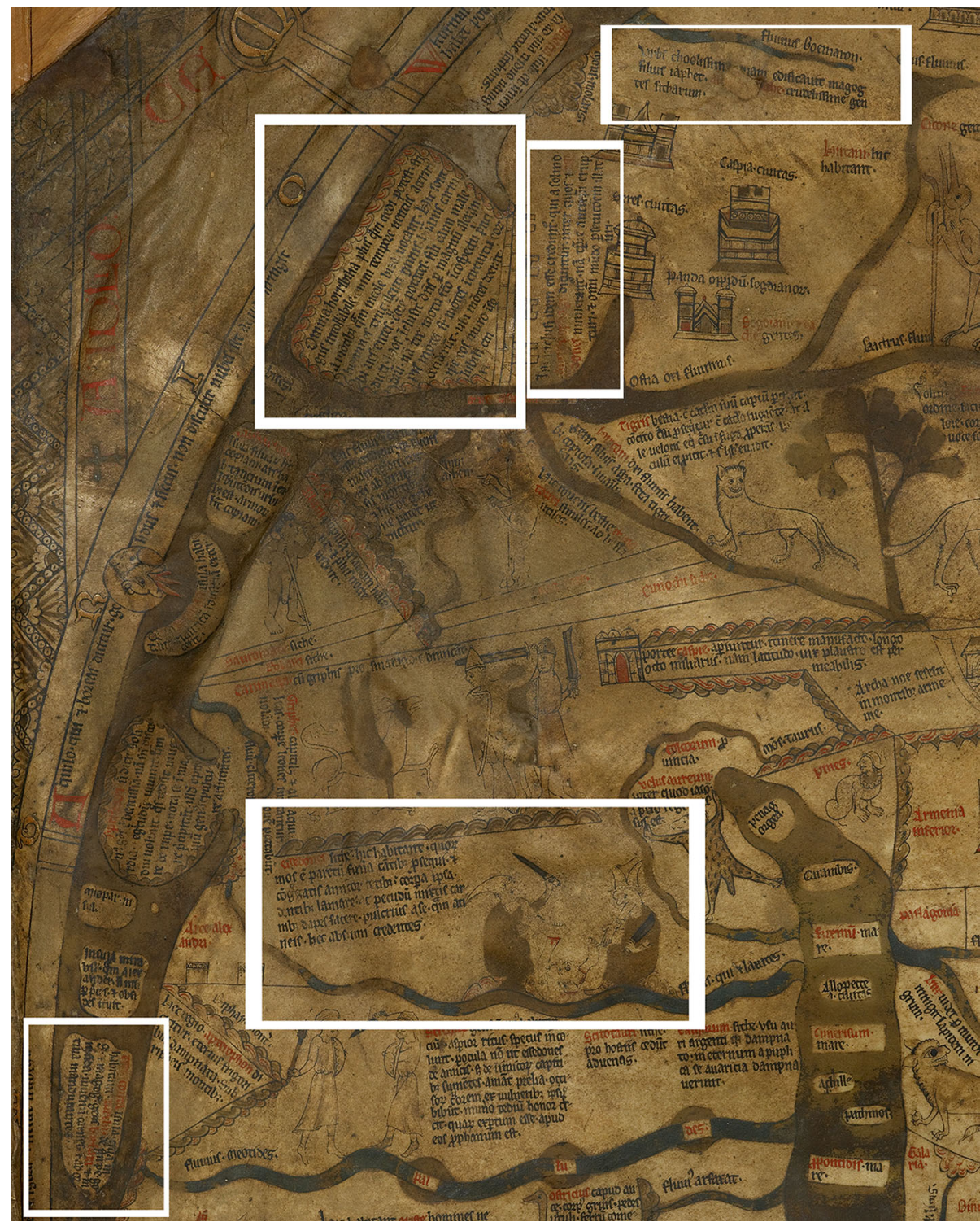

Figure 2: Detail of North East Region with Gog and Magog Circled, Hereford Map, Hereford Cathedral, ca. 1303, by permission of the Dean and Chapter of Hereford and the Hereford Mappa Mundi Trust.

maneuver was already well-practiced by medieval English cartographers. For example, on the thirteenth-century Vercelli Map, beside the Caspian Gate, we read, 'Here is the gate that God made through Alexander's prayer, so that the Jews would not come out [...] to lay waste to the world' (Chekin, 2006, 144-45, emphasis added). 


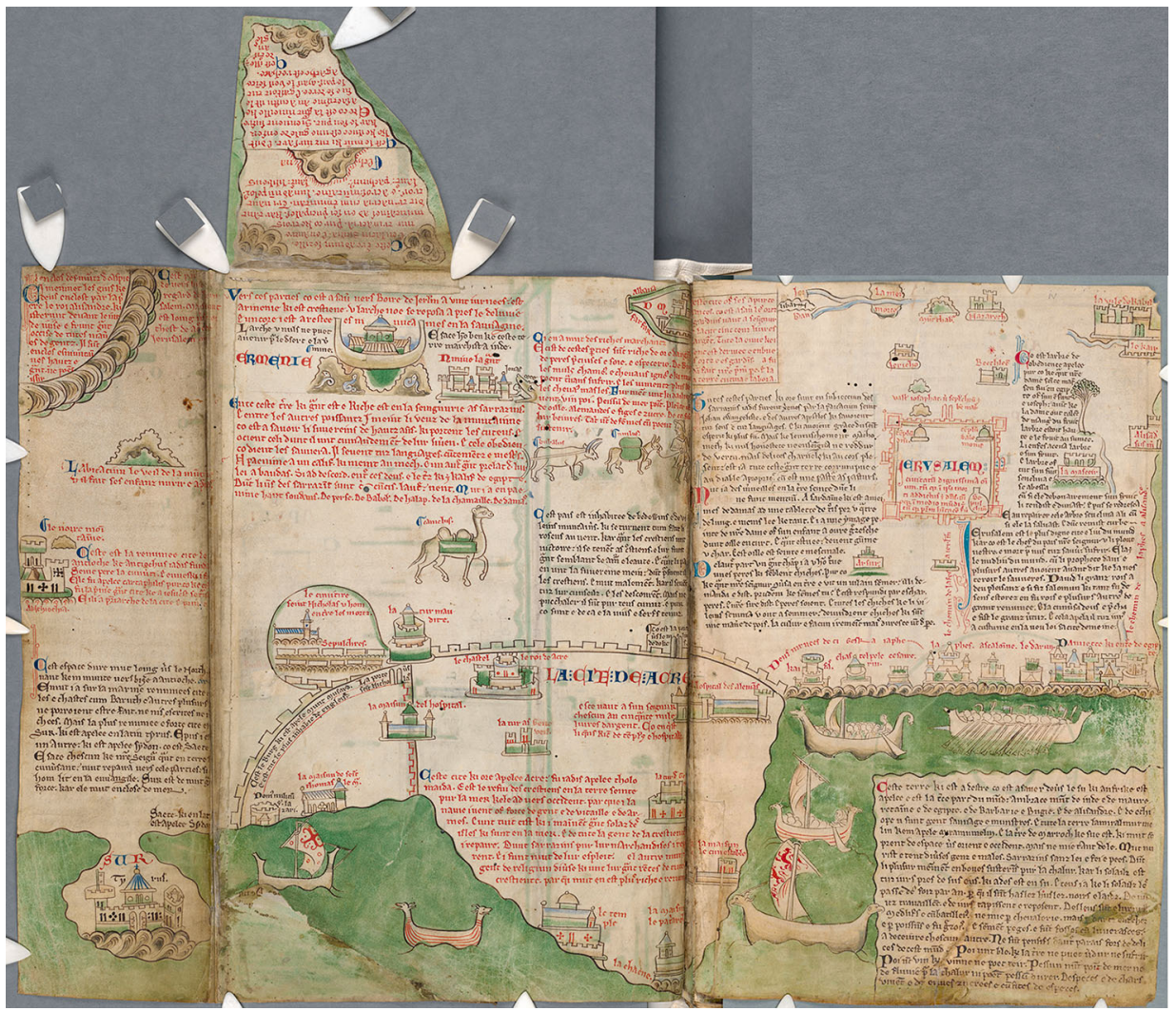

Figure 3: Matthew Paris, Map of the 'Holy Land,' ca. 1250, Cambridge, Corpus Christi College Library, MS 26, fol. iii v-iv r. Photo: by permission of the Master and Fellows of Corpus Christi College, Cambridge.

Matthew Paris writes behind the Wall of Gog and Magog on Cambridge, Corpus Christi College MS 26, one of his mid-thirteenth-century maps of the 'Holy Land': 'Here dwell the Jews [...] who will come forth on the eve of the Day of Judgment and will [...] openly massacre all the people' (Figure 3). This inscription is similar to the ones on his other maps. Matthew is careful to note here that 'They are enclosed by high and great mountains and cannot get out.' On Hereford, however, while Gog and Magog are shown behind the Wall, they also appear three additional times in both text and image. In all of these cases, they are outside of the wall. Here, they are presented in series of grim texts and images. To the southeast of the wall is the city of Choolissime, 'quam edificavit Magog' ['which Magog ... built'], wherein live 'crudelissime gens' ['the cruellest people'] (Westrem, 2001, 47); to the northwest, in the circle of the ocean, is the island of Terraconta, which contains 'de stirpe Gog et Magog: gens barbara et inmunda, iuvenum carnes et abortiva manducantes' ['the lineage of Gog and Magog, a barbarous and filthy people who eat the flesh of youths and miscarried 
fetuses'] (Westrem, 2001, 137) and, to the west, rounding out this district of horror, are the Essedones - among those walled up in the Caspian Mountains that 'nam tempore Antichristi erupturi et omni mundo persecucionem illaturi' ['at the time of Antichrist will be bursting forth and inflicting persecution on the whole world'] (Westrem, 2001, 71) - shown calmly feasting on the dismembered corpses of their own parents. ${ }^{2}$ They should be locked up, over there, until some future time, but again are now, and seem in motion toward the map's here.

One of the main operative principles of world maps - Hereford included - is that they are devices for talking about the local through the presentation of the global. Martin Foys has convincingly argued, for example, that the earlier Cotton Map presents Britain as a microcosm of the world in order to make claims about the status of this marginal island (Foys, 2007, 110-58). While on Hereford, Britain does not mimic the shape of the world, as it does on the Cotton Map, it is in constant and various dialogues with the rest of the great circle. Anti-Jewish rhetoric is one of the threads binding the whole together. The Hereford texts and images discussed here, and related inscriptions on the three Matthew Paris maps (as well as on the thirteenth-century Ebstorf Map, see Mittman, 2013a, 93), reconstruct the world as imperiled by the tiny Jewish minority by conflating the End-Days narrative of Gog and Magog with contemporary Jews. The Hereford Map was made about a dozen years after all Jews were expelled from England in 1290 by the decree of Edward I. This was a period of intense rhetorical anti-Judaism and anti-Semitism in text and image, as the English continued to define themselves against what others have called the Hermeneutic Jew, the imagined evil Jew of Christian fantasy (Krummel, 2011, 120). ${ }^{3}$

While Jews were in England, English Christians used them to define themselves, built their national identity from the bones of actual Jews, and, from the charred rubble of their burned ghettos, reassembled them into horrifying form, reanimated like so many rebellious golems. After 1290, Jews were cast out from the microcosm of England, but still roamed the world - by necessity, according to many Christian theologians, either as punishment for sins, like Ahasuerus the Wandering Jew, or as 'living letters,' 'tolerated' because they tolerate, they support Christian scripture through their subjugated existence (Kupfer, 2008, 100-11). On Hereford, as on many medieval maps, the Jews are made to wander both through time and space. The image of the Wandering itself - that is, the Israelites' forty years of wandering in the desert, between the Exodus from Egypt and their arrival in the Promised Land, detailed in the biblical book of Numbers - rendered in gold and measured out in hash marks like so many footsteps, therefore becomes something of a metonym for the Christian conception of the Jews as a people ever on the move and, as here, roaming ever perilously closer to the center of affairs. In Hereford's presentation both of the Wandering, from Egypt toward Jerusalem at the map's center, and of Gog and Magog, from the east toward England, these ancient and apocalyptic
2 For further discussion of the Essedones, see Mittman (2006), 92-95, 104.

3 See also Tomasch (2000), 243-60. 
4 This mirrors the treatment of Jews in the popular Book of John Mandeville, wherein Jews are also displaced in time and geography. For example, the Book says that Jesus was called King of the Jews because 'at that time this land belonged to the Jews' (emphasis added, Higgins, 2011, 107).

5 It is worth noting that the map has an equivalent effacement of Muslims; no mosques are shown, towns are all labeled in Latin regardless of Muslim control of much territory, and there are no images of Muslim rulers. See also Mittman (2013b), 153 , for analogous maneuvers in Matthew Paris's mapping.

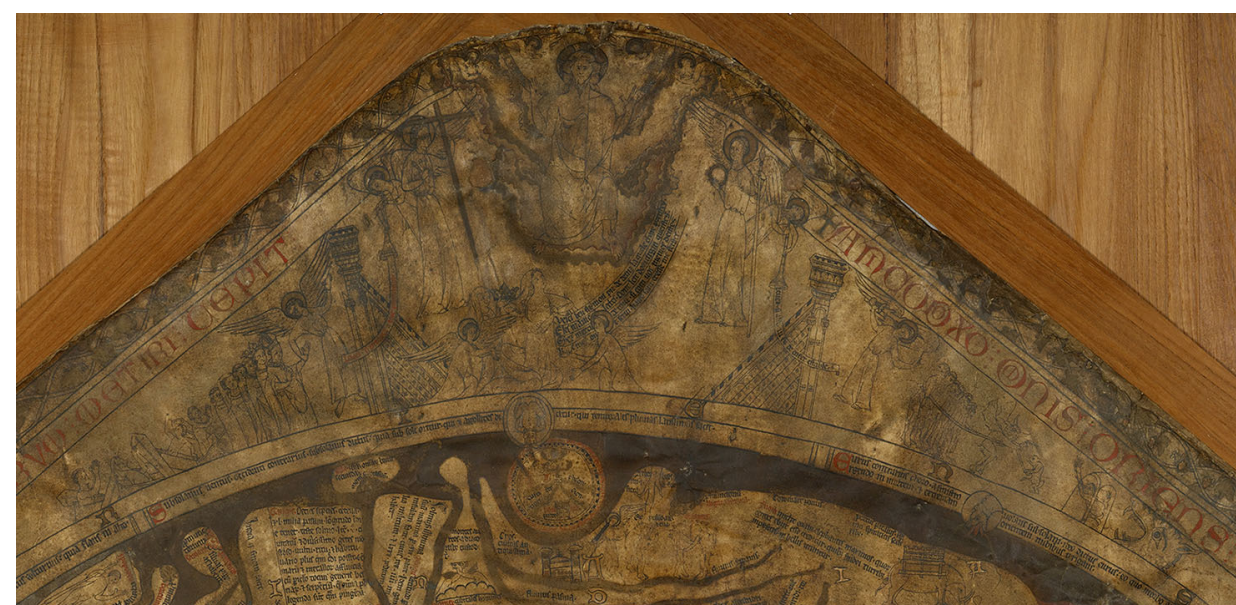

Figure 4: Detail of Judgment, Hereford Map, Hereford Cathedral, ca. 1303, by permission of the Dean and Chapter of Hereford and the Hereford Mappa Mundi Trust.

'Jewish' groups become present threats. Indeed, the Hereford Map actively participates in the common Christian fantasy that Jews lack any permanent residence by excluding from its 1,091 inscriptions any text that would imply current Jewish ownership of territory, ${ }^{4}$ and from the accompanying images any synagogues, though there are many structures that are at least evocative of church architecture. ${ }^{5}$ The existence of these fictionalized Jews, of Gog and Magog and the idol-worshipping Iudei - as well, of course, as that of so-called 'Saracens' of Crusader fantasy - lent 'Christendom' its meaning, and thereby called it into being. We do read at the end of the path of the Wandering that 'Usque ad civitatem Ierico ducebat Moyses populu[m] Israel' ['As far as the city of Jericho Moses led the People of Israel'], but this is twice removed from Jewish possession of territory in that it is an event of the distant past, and even then, the Israelites were just passing through (Westrem, 2001, 165). Thus, this inscription works, too, towards the Hereford's project of anti-Judaic world-building insofar as it does not confirm any fixed and proper abode for Jewish peoples, even in the distant past, thereby delegitimizing Jews of their own period as permanent holders of any territory.

The Crusader dream was to 'free' Jerusalem, to evacuate it of Jewish and Muslim inhabitants and transform it into a Christian city, or perhaps, by the time the Hereford Map was produced, to return it to the idealized state in which it was briefly held as part of the Crusader Kingdom (Mittman, 2013b, 153). This, though, was merely a way station on the way to the Heavenly Jerusalem, a realm that would, by definition, be a perfect Christendom, a land occupied by Christians and ruled by Christ as King of Heaven, and by Mary as his queen. Unsurprisingly then, Christ sits in majesty in the lunette at the top of the Hereford Map (Figure 4). Scott Westrem is correct that 'there is no trace of a 
throne or a chair,' but that is because here the clouds of Heaven are his throne (Westrem, 2001, 4). His crown is the Crown of Thorns, rendered as a smooth circle of gold, held up by an angel to his left. Below him, an angel offers Mary her crown. The map was part of a larger world-building project in which, as Britain might be microcosm of the ecumene, so Christendom would be a foreshadowing of Heaven. In this way, the Hereford Map sets up a contrast between the present world, still filled with monstrous peoples, and the next world, dawning in the Judgment scene above.

This image of Heaven - and that of Hell to the right - is outside of the geography of the ecumene. It is part of what Wood calls the 'perimap,' 'a crowd of signs: titles, dates, legends, keys, scale, statements, references, footnotes, potentially any device of visual expression' by which the map 'is surrounded, sometimes invaded' (Wood et al., 2010, 97). It is outside of the geography, but also outside of the chronology of the map, with its east to west, past to present drive. In this way, both Heaven and Hell become permanent homes for their occupants. We should not, then, be surprised to find that one of the figures being dragged toward the mouth of Hell bears a profile that matches that of the Jew worshipping the golden calf. By contrast, the map stresses the temporary nature of any earthly residence of Jews. Bishop Robert Grosseteste of Lincoln, much more sympathetic to Jews than the maker of the Hereford Map, at least imagined that Jews once had a proper place. He wrote in 1231 or 1232 that 'they (the Jews) are a wandering people through their diaspora and they are fugitives from their proper home, that is Jerusalem ... This people is vagrant because of the dispersal, and an exile from its own home, that is, Jerusalem' (Mantello and Goering, 2009, 68). Even Robert's compassionate perspective remains in accord with the map's presentation of unsettled (and, to its Christian audiences, unsettling) Jews.

The maker of the Hereford Map and his contemporaries were certainly not the first to imagine a world wherein they and their culture reigned supreme. As demonstrated by the presence of the Roman Emperor Augustus - presented in a papal tiara and therefore as if he were a Holy Roman emperor - in the lower left corner of the map, Plantagenet kings saw themselves as the inheritors of power and legitimacy to rule. This imagined process of translatio imperii from Greece to Rome to various medieval powers is embedded throughout the map, most prominently in the image of Augustus and the inclusion of at least 69 details from the legends of Alexander the Great (e.g. The Trees of the Sun and the Moon and the Altars of Alexander in the far east) (Kline, 2006, 167). Despite these allusions to great rulers of the past, the circumstances in England at the end of the thirteenth century were profoundly different from those that obtained in the perceived glory days of old Rome, or of Alexander. Diarmuid Scully provides an index of this dissemblance by drawing attention to the great confidence conveyed by Eumenius, a late third-century orator, who imagines a classroom world map: 'Nunc enim, nunc demum iuvat orbem spectare 
depictum, cum in illo nihil videmus alienum' ['it is a delight to see a picture of the world, since we see nothing in it which is not ours'] (Scully, 2013, 117 and Nixon and Rodgers, 1994, 20.2 and 21.3). As Scully argues, the Hereford Map reflects the ways that 'Anglo-Norman kings viewed themselves as the heirs to the imperium' that had been Rome's, and then had transferred to Frankish and German rulers (Scully, 2013, 111). While it is striking that both Eumenius and the Hereford Map evince desires to imagine a world in which one's cultural aspirations are fully realized, there is a profound difference, because Rome did have a robust empire at the time Eumenius was writing, whereas a comparable Christian 'empire' was an aspirational fantasy at the time the Hereford Map was produced. There was, in a very real way - enforced through military power and taxation but also supported by defense networks and social services - a Roman empire; in essence, and in contrast, there was no Christendom except as it was invoked through documents including the Hereford Map.

The project of Christendom was, by necessity, a universalizing one, deeply ambitious and correspondingly exclusionary. The Hereford Map is one node in this vast effort, which included many other maps, as well as texts such as The Book of John Mandeville and Matthew Paris's Chronica Majora (Mittman, 2016). As English Christians expelled Jews from within their midst, so they hoped ultimately to expel these 'wandering people' from their world. This process began in England, and spread throughout much of Europe in the following centuries. Given the proto-racialization of Jews in the Middle Ages (Heng, 2011, passim), it is possible to see the endgame for this process unfurling in the scene at the top of the map, wherein Judgment becomes the final and complete act of ethnic cleansing. The larger world-building process of which the Hereford Map was a grand and carefully constructed part did not remain in the social imaginary of fourteenthcentury Christian English culture. Rather, it followed great bursts of violence and exclusion and encouraged more elsewhere, while simultaneously justifying that which had already occurred locally. In 1287, three years before the Edict of Expulsion, the entire Jewish population of England was imprisoned; in Hereford, they were incarcerated in a specially reserved 'Jews' prison, which was below the ring wall of the castle keep,' located less than a quarter of a mile from the Cathedral, where the map was housed (Mundill, 2003, 61). Judicial and carceral institutions functioned in tandem with artistic and textual efforts at exclusion.

Nearly an hour and a half into The Wizard of $\mathrm{O} z$ (Fleming, 1939), the film from which this collection takes its name, Dorothy and her friends confront the Wicked Witch of the West within her gloomy ersatz Gothic castle. The greedy witch, who uses arcane knowledge and evil magic to gain power for malicious ends, has a long, hooked nose and wears a pointy hat, which is all to say that she is an iconic modern recreation of medieval anti-Jewish tropes - though in the Middle Ages, as in the cinematic prototype Der Golem, wie er in die Welt kam (Paul Wegener, 1920), the archetype Jewish magician is male. The witch uses her broom to light the Scarecrow on fire, and Dorothy, the hero of the tale, tosses a bucket of water on her 
in a poorly aimed attempt to save her friend. The witch famously melts away while calling out piteously, 'Oh - what a world - what a world!' Dorothy immediately ducks responsibility: 'I didn't mean to kill her [...] really I didn't! It's [...] it's just that he was on fire!' In this way, the 'good little girl,' as the witch calls Dorothy during her death throes, remains 'good,' unstained by the murder she commits. There was a fire, so she threw water, no more. Killing off this witch allows Dorothy to escape the land of wonder, riches, and enchantment that might just as well be the land of Prester John, back to safe, 'normal,' homogenous Kansas.

The Hereford Map presents its world in strikingly similar ways - endangered as if by fire, where violent hordes of the 'cruellest people' eat babies to fuel their encroachments toward England. And so, as the logic of its cultural imaginary goes, if local families - shopkeepers, bakers, butchers, scribes, rabbis, and, yes, moneylenders - were caught in the crossfire, it's only because someone, somewhere, something was on fire in the first place.

\section{About the Author}

Asa Simon Mittman is a Professor of Art History at California State University, Chico and the author of several books and articles on monstrosity and marginality in the Middle Ages. He is the founding president of MEARCSTAPA and a founding member of the Material Collective. See http://myweb.csuchico. edu/ asmittman/ (Email: asmittmann@csuchico.edu).

\section{References}

Borges, J.L. 1975. On Exactitude in Science. A Universal History of Infamy. Trans. N.T. di Giovanni. London: Penguin Books.

Borges, J.L. 1999. Collected Fictions. Trans. A. Hurley. London: Penguin Books.

Cassidy, F.G. and R.N. Ringler, eds. 1971. Bright's Old English Grammar and Reader. 3rd ed. New York: Holt, Rinehart and Winston.

Chekin, L.S. 2006. Northern Eurasia in Medieval Cartography: Inventory, Texts, Translation, and Commentary. Turnhout, Belgium: Brepols.

Delano-Smith, C. and R. Kain. 1999. English Maps: A History. Toronto, ON: Toronto University Press.

de Wesselow, T. 2013. Locating the Hereford Mappamundi. Imago Mundi 65(2): 180-206.

Finucane, R.C. 2004. Cantilupe, Thomas de [St Thomas of Hereford] (c.1220-1282), Oxford Dictionary of National Biography. Oxford, UK: Oxford University Press, 2004. http://www.oxforddnb.com/view/article/4570.

Fleming, V., dir. 1939. The Wizard of Oz. Metro-Goldwyn-Mayer. 
Foys, M.K. 2007. Virtually Anglo-Saxon: Old Media, New Media, and Early Medieval Studies in the Late Age of Print. Gainsville, FL: University Press of Florida.

Heng, G. 2011. The Invention of Race in the European Middle Ages I: Race Studies, Modernity, and the Middle Ages. Literature Compass 8(5): 258-74.

Higgins, I.M. 2011. The Book of John of Mandeville, with Related Texts. Cambridge, MA: Hackett Publishing.

Hillaby, J. 2013. Prelude and Postscript to the York Massacre: Attacks in East Anglia and Lincolnshire, 1190. In Christians and Jews in Angevin England: The York Massacre of 1190, Narratives and Contexts, eds. S. R. Jones and S. Watson, 43-56. York, UK: University of York Press.

Kline, N.R. 2006. Alexander Interpreted on the Hereford Map Mappamundi. In P. D. A. Harvey, The Hereford World Map: Medieval World Maps and their Context, 167-83. London. The British Library.

Krummel, M.A. 2011. Crafting Jewishness in Medieval England: Legally Absent, Virtually Present. New York: Palgrave MacMillan.

Kupfer, M. 2016. Art and Optics in the Hereford Map. New Haven, CT: Yale University Press, with the Paul Mellon Centre for Studies in British Art.

Kupfer, M. 2008. '...lectres ... plus vrayes': Hebrew Script and Jewish Witness in the Mandeville Manuscript of Charles V. Speculum 83(1): 58-111.

Lavezzo, K. 2011. The Minster and the Privy: Rereading The Prioress's Tale. PMLA 126(2): 363-82.

Leshock, D.B. 2002. Religious Geography: Designating Jews and Muslims as Foreigners in Medieval England. Meeting the Foreign in the Middle Ages, ed. A. Classen. New York: Routledge, 202-25.

Lewis, C.S. 1964. The Discarded Image: An Introduction to Medieval and Renaissance Literature. Cambridge, UK: Cambridge University Press.

Mantello, F.A.C. and Joseph Goering, trans. 2009. The Letters of Robert Grosseteste, Bishop of Lincoln. Toronto, ON: University of Toronto Press.

Mittman, A.S. 2006. Maps and Monsters in Medieval England. New York: Routledge.

Mittman, A.S. 2013a. Gates, Hats, and Naked Jews: Sorting out the Nubian Guards on the Ebstorf Map. FKW: Zeitschrift für Geschlechterforschung und visuelle Kultur 54: 89-101.

Mittman, A.S. 2013b. Forking Paths? Matthew Paris, Jorge Luis Borges, and Maps of the Labyrinth. Peregrinations: Journal of Medieval Art \& Architecture 4(1): 134-60.

Mittman, A.S. 2016. Mandeville's 'East,' Colonialism, Certainty, and Art History. In Postcolonising the Medieval Image, eds. E. Frojmovic and C. Karkov, 91-119. London: Ashgate.

Mundill, R.R. 2003. Edward I and the Final Phase of Anglo-Jewry. In Jews in Medieval Britain: Historical, Literary and Archeological Perspectives, ed. P. Skinner. Woodbridge, UK: Boydell Press.

Nixon, C.E.V. and B.S. Rodgers, eds and trans. 1994. In Praise of Later Roman Emperors. The Panegyrici Latini: Introduction, Translation and Historical Commentary with the Latin Text of R. A. B. Mynors. Berkeley, CA: University of California Press.

Scafi, A. 2006. Mapping Paradise: A History of Heaven on Earth. Chicago, IL: University of Chicago Press. 
Scully, D. 2013. Augustus, Rome, Britain and Ireland on the Hereford Mappa Mundi: Imperium and Salvation. Peregrinations: Journal of Medieval Art and Architecture 4(1):107-33.

Strickland, D. 2015. The Place of the Jews on the Hereford Map. Presented at Ben Gurion University, 2 June. On file with the author.

Terkla, D. 2004. The Original Placement of the Hereford Mappa Mundi, Imago Mundi 56(2): 131-51.

Tomasch, S. 2000. Postcolonial Chaucer and the Virtual Jew. In The Postcolonial Middle Ages, ed. J. J. Cohen. New York: Palgrave, 243-60.

Tout, T.F. 1886. Cantilupe, Thomas de. Oxford Dictionary of National Biography 8, ed. L. Stephen and S. Lee. New York: MacMillan.

Wegener, P., dir. 1920. Der Golem, wie er in die Welt kam. Projektions-AG Union.

Westrem, S. 2001. The Hereford Map: A Transcription and Translation of the Legends with Commentary. Turnhout, Belgium: Brepols.

Wolf, M. 2012. Building Imaginary Worlds: The Theory and History of Subcreation. New York: Routledge.

Wood, D., J. Fels and J. Krygier. 2010. Rethinking the Power of Maps. New York: The Guilford Press.

Woodward, D. 1985. Reality, Symbolism, Time, and Space in Medieval World Maps. Annals of the Association of American Geographers 75(4): 510-21. 